\title{
The Metamorphosis of a Female Subject into a Gendered subject: A Study of Easterine Iralu's A Terrible Matriarchy
}

\author{
Bompi Riba ${ }^{1}$ and Karngam Nyori ${ }^{2}$ \\ ${ }^{1}$ Assistant Professor, Department of English, Rajiv Gandhi University, Arunachal Pradesh, Pin- \\ 791112, ORCID id: 0000-0002-0341-2348. E-mail: bompi.riba@rgu.ac.in \\ ${ }^{2}$ Ph.D Research Scholar, Department of English, Rajiv Gandhi University, Arunachal Pradesh, Pin- \\ 791112, ORCID id: 000-0002-3477-141. Email: nkarngam@yahoo.com
}

\begin{abstract}
It is a universally practised phenomenon across society to conveniently create a dichotomy that is based on the physiological difference between a male and a female. This difference is further defined by the dichotomy of gendered roles and labour that are imposed on them. The hegemony of the gendered ideology makes it all so natural to assign gendered role to a baby the moment it is born. Its body serves as a continuing signifier for the gendered structure of a patriarchal society. Since these gendered ideologies are disseminated through established institutions such as education, religion and law; their manifestations can be found in culture, religion, clothes, discourse, movies, and even in gestures that this polarity between a man and a woman is accepted as natural. There still is no general consent among the cultural anthropologists that an unambiguous matriarchal society existed. Classical scholar like Johann Jakob Bachofen tried to argue that matriarchal society existed on the basis of unreliable historical sources such as Iliad and Odyssey (Bamberger, p.263). Easterine Iralu's $A$ Terrible Matriarchy intrigues the reader with this highly deceptive title that ironically bares the patriarchy of the contemporary Naga society. However, if these reasons are taken into account that Feminism is all about equality and that matriarchy is the flip side of patriarchy with all its horrors; then she is not far from the truth in prefixing "terrible" to "matriarchy". This article is an attempt to familiarize the milieu of a quintessential Naga girl and her resistance to the anxious process of self-denial imposed upon her by her grandmother who embodies the concept of 'terrible matriarchy'. The article also concentrates on the typical mechanism of gender construction and how such mechanisms are responsible for metamorphosing a female subject into a gendered subject.
\end{abstract}

Key words: Angami-Naga society, female subject, gendered subject, matriarchy, patriarchy

\section{Introduction:}

"Well, I don't care about being a good woman. I shan't ever be a good woman, whatever that is," (Iralu, A Terrible Matriarchy, 39)

This was the cry of a six years old girl who resisted the initial stages of metamorphosis into womanhood. It also emphasizes on the stereotyped dichotomy of good and bad women as the society sees it. This paper deliberates on the struggle of the narrator in withstanding the social demands of being a quintessential Naga woman. How much was she autonomous in expressing 
and exploring her 'Self' in the narration? Was she consciously camouflaging her true desire in her narrative in order to avoid the social disapproval and the resultant shame associated with it? She was obviously not totally autonomous from the psycho-social distinctions and cultural mechanisms of gender constructs. The conscious fear of the 'gaze' is visible in her narrative. And the society in question is very much a practicing patriarchal one. So the question that intrigues the readers is why 'matriarchy' is terrible as suggested by the title of the novel.

Did the author deliberately prefix the adjective 'terrible' to 'matriarchy' in the title ' $A$ Terrible Matriarchy' ambiguously? Does the term 'matriarchy' here refer only to the power exercised by an old woman over her family? Or is the family a miniature version of a larger society that has women playing the central roles in the governing of the various institutions of the same? Does the 'terrible matriarchy' have a cultural connotation? Is the author suggesting that matriarchy, if existed, being the flip side of patriarchy would be as appalling as the latter? Or the story does not convey any farfetched ideas at all other than the plain story of Dielieno and her relationship with her grandmother Vibaso who is the terrible matriarchy for the little girl. The grandmother does have economic advantage over her relatives. But will it be right to address grandmother Vibaso as a 'matriarch' while she is not exactly powerful and is also marginalized by her own family members? The family's preference of their grandfather's testament on property distribution over their grandmother's last wish that the house should go to her great-grandson Salhou is one such instant. Simone de Beauvoir in her 'The Second Sex' contends that one of the maledictions of being a woman is to be left in the hands of women during childhood. (Beauvoir, 1989, p. 281) This confirms the influential role of mothers as conservators of patriarchal values though there might be exceptions. However, Kate Millet rightly points out that "male and female are really two cultures and their life experiences are utterly different." (Millet, 2003, p. 31)

\section{Angami Naga society}

Easterine Kire is a well-known writer from Nagaland who writes in English. She has written a good number of novels, poems and short stories. Most of her writings are about Naga people and their society. She has lucratively captured not just the true essence of Naga life by exploring their oral history but also their problems and the trauma caused by the insurgency conflicts. The novel $A$ Terrible Matriarchy 2007) revolves around the lives of Dieleino, Nino and Vibano representing three generations of Angami- Naga women of the same family. The Angami tribe is one of the major tribes of Nagaland. Almost all the Angami population is Christian with only a meager population out of it that still practice animistic belief. Christianity as a religion is patriarchal in nature as it focuses on man's relationship with the Holy Trinity. It also preaches man to love his wife and the wife to be submissive to her husband as he is the head of the house. With such religion in practice, one cannot fathom the idea of a matriarchal society in an Angami village. Therefore, as mentioned above, grandmother Vibaso might be a matriarch of the family but she is as insignificant as the 'others' in the larger society.

Like most of the tribal societies, even the Angamis, while assimilating foreign religion and culture has also retained much of its traditional values. A glimpse of the culture in the narratives again exposes the passive roles of women in the society. For instance, when Lieno's maternal grandmother died, her grandfather married for the second time. But it was not the same case with grandmother Vibaso's mother. She was a widow and according to their custom, those widows 
who do not have sons would be dispossessed of their husbands' property which will be taken over by the other male relatives of the family. Grandmother Vibaso was a witness to the suffering of her mother. And Lieno's mother was of the opinion that experiences such as these have hardened grandmother and conditioned her to look at 'her sons and grandsons as a kind of insurance.' According to grandmother Vibaso,

In my father's days, boys... had to look after the village and engage enemy warriors in warfare. The household that did not have a male heir was considered barren... That is why we love our male children so much and we give them the best of food. And we should. (Iralu,2007, p. 37)

This particular comment of the grandmother seemed reasonable to her. She was brought up to think that 'women have to be dependent on men... It is difficult to unlearn things learnt in childhood.' (p. 274) Lieno's sister-in-law, Nisano, after the death of her husband Vini, lived in grandmother's house and that explains why she was not spared from ill gossips about her.

The girl is Vinilhoulie's widow, she should live with his parents for a year before she goes back to her father's house... Why should she go to live with his grandmother...? Doesn't the old lady know that there is no such custom? (p.257)

Some even accused the grandmother of trying to initiate a new custom by seizing the privilege of the service of Nisano to her in-laws by sheltering her and her son. Their reasoning was that she could afford to do that. But she was eighty-eight and could not overcome her grief at the sudden death of Vini. And she tried to compensate the loss of Vini by loving and pampering her greatgrand son.

\section{The Terrible Matriarchy}

Grandmother Vibaso loved all her grandsons but Vini was the closest to her. According to Lieno's mother, grandmother's attempt to buy love and loyalty from her grandsons by giving them money, did only more harm than good to Vini. She wanted Vini to inherit her house. But after Vini's death, she chose her great-grandson Salhou as the heir of her house. This wish of hers seemed to come in conflict with the custom of the community, according to which, the youngest son inherits the parental home and takes care of the old folks until their death. She also did not have any legal documents to support her wish against the will of the grandfather, which was of course a modern concept. So, when Bano, Nisano and Salhou vacated the house for the tenants; her spirit displayed her disappointment at various instances with vengeance. There were instances reported of an old woman staring angrily at the occupants. Here one is reminded of the Medusa archetype. According to Susan R Bowers,

"Medusa becomes again what she was once for women, an electrifying force representing the dynamic power of the female gaze." (Alban, p. 163)

Gillian M. E. Alban in her essay "Medusa as Female Eye or Icon in Atwood, Murdoch, Carter and Plath" articulated that Medusa was a victim of rape and so she avenged herself by petrifying her enemies with her glare. (p. 163) The spirit of Grandmother Vibaso saw herself as a victim of the animate world which was in her case primarily a patriarchal one. But interestingly most of her 
malevolent glare and the physical aggression such as throwing a kitchen stool were exerted mostly on the women occupants while she asked the male occupants verbally to leave the house or made her presence felt by stomping on the roof or banging on the walls and making other terrible noises.

Though she is the terrible matriarch of " $A$ Terrible Matriarchy", she was not fully autonomous. And one wonders why this adjective for the old woman by her own granddaughter. One of the possible explanations for Lieno's fear and dislike of her grandmother could be her fear of her grandmother's encroaching symbiosis in her which she resists from the very beginning of the narration. The novel opens with Dielieno aka Lieno's blunt statement,

"My Grandmother didn't like me. I knew this when I was about four and a half." (Iralu, 2007, p. 1)

This could also be one of the reasons for her dislike of her grandmother. She probably thought it was only mutual. The above statement was uttered in the context of grandmother's ostentatious display of affection for her grandsons and the reverse of the same for her only granddaughter. The fact that she enjoyed running and climbing like her brothers and felt more comfortable wearing stained t-shirts and torn-at-the knees boys' trousers over girl's frocks; she felt that she wasn't different from her brothers. But she was 'indoctrinated with her vocation from her earliest years" (Beauvoir, 1989, p. 269) by others. Whenever she complained that her grandmother was hostile towards her; she was given assurance that it was for her own good. This only succeeded in creating a negative perception of her gender and placing the opposite sex as the superior one in her. An illustration from the narrative is her admission of wanting to be a boy so that her grandmother takes her on her lap and showers her with her love and also gives her more meat, preferably "the leg", the portion of meat reserved only for boys. But she had to be contented with what she got, which was just one or two pieces of dried meat.

According to Judith Butler, 'gender is a set of expectations that society define for you'; The fact that Dielieno was sent to her grandmother's house to stay as a helper can be considered as an example of 'social learning' (Bussey, p. 12) that explains how gender role operates. It is found that gender hierarchy is often expressed through food in which case women have less access to food than men. This practice is supported by belief that they eat less and mostly because of their economic dependence on men. In the case of Dielieno, food was used as a powerful medium to subordinate her. She did not understand why she was being deprived of her favourite piece of chicken leg by her own grandmother. She also noticed that it was not only her grandmother but also her mother who gave such special treatment to her brothers. This is, in fact, an evident of how this small practice of serving special food for male progeny is deeply gender-biased.

\section{Gendered Performativity}

Just five years old and yet Dielieno could comprehend the sexual division of labour in the family, based on the repetitive "gendered performatives" (Wendy A. Burns, p. 43) that she had observed.

"Mother worked very hard to make the small four-roomed house cheerful... Father did not help much. He would expect Mother to clean the house and wash all the clothes and have cooked food ready when he got home." (Iralu, 2007, p. 49) 
One may call her precocious but she understood at a very early age that it was her father who has the last say on all the important discussions between her parents. This fact in itself is indicative of 'family' being the first representative of patriarchal authority. Though she does not literally question that authority but she is disturbed to learn that a girl child cannot carry her father's name. She also feels degraded when her grandmother frequently addressed her as 'the girl' and not by her name. She is therefore made to see "her objective self" (Beauvoir, 1989, p. 280) as the 'other'. She does not find any logic in the biased law of the society. Her illegitimate cousin Bano, who was adopted by her grandmother in order to avoid rumours about family scandals, explains her about the socially accepted perception about being a girl,

...girl-children are never considered real members of the family. Their mission in life is to marry and have children and be able to cook and weave cloth and look after the household. If they got married, they would always be known as somebody's wife or somebody's mother and never somebody's daughter. That way they could not carry on their father's name. (Iralu, 2007, p. 26)

Most feminists believe that patriarchy in some way is degenerative in nature. Though there are still controversies regarding the existence of primitive matriarchal societies; feminists believe that matriarchal society is an egalitarian one. But somehow that idea does not correlate with the idea of power. Power is exercised by the strong ones over the weaker ones who are the 'others'. In that context, it would be right to claim that matriarchy is but patriarchy with a different sex in authority. This particular argument can be elucidated by the strange dream of Lieno that wakes her up in fear.

In my dream, I saw Grandfather walking ahead of me. I ran up to him, having quite forgotten that he was dead. I tugged at his hand and we were playing together when his face suddenly changed and he became Grandmother and she shook off my hand and gave me such a stern look that I woke up suddenly, in fear. (p.11)

If we consider the grandfather in the dream as the displaced father figure; then, the idea evokes the concept of the Electra complex Lieno has for her father. As revealed in the above discussion that she has understood very early that it is not her mother who occupies the privileged position in the house but it is her father who controls the family. For instance, when her brother Vini frequented the drinking houses and was frequently involved in brawls; it was her father who confronted him while her mother helplessly cried for her spoiled son. It was again her father who decided in spite of her mother's apprehension to send Lieno to her grandmother's house to be raised properly. This revelation assent with the argument made above that one can exercise power over those who fear him. And grandmother who is the matriarch here, no doubt has the reverence of her relatives but they, particularly the women relatives, also fear her. And the added advantage for her is that she is not financially dependent on anyone because of the pension of her dead husband.

\section{On Educating Women}

When Lieno's parents sought grandmother's permission regarding Lieno's education; the matriarch's response corresponded to the views that are still being upheld by many patriarchal 
societies. In this context one can also refer to the opinion of Jean-Jacques Rousseau on the issue of women education as was quoted by Kate Millet in her Sexual Politics (2003)

The whole education of women ought to be relative to men. To please them, to be useful to them, to make themselves loved and honored by them, to educate them when young, to care for them when grown, to counsel them, to make life sweet and agreeable to them - these are duties of women at all times, and what should be taught them from their infancy. (Millet, p.74)

Her argument also seemed to echo the views of many folks in the contemporary tribal society, according to which girls should stay at home and learn the housework to avoid getting into trouble.

It is alright if boys have a spot of trouble now and then, but with girls, it is different. You would never be able to get rid of her once she has caused trouble. I really do not approve of girls getting educated. It only makes them get fancy notions about themselves and they forget their place in the family. (Iralu, 2007, p. 23)

Grandmother also seemed to have a valid point for her disapproval of girl's education.

"Men hesitate to court a woman who has too much education. They also do not like to take someone as wife who is not often seen at home." (p.104)

Education, however, gives Lieno a scope to think and question. Though the narrator in the beginning is just a five-year-old girl; the reader is all the time aware of the matured Lieno narrating her story. She raises important issues in her narrative such as, the clothing of children that has great effect on the feminine psychology.

I sometimes felt I was an afterthought, and maybe Father and Mother didn't quite know what to do with me. Also, because I was a girl after four boys, they never seemed to be sure whether to buy me girl's clothing or let me wear leftover boy's clothing. (p.2)

The above extract clearly displays Lieno's parents' confusion regarding her upbringing; whether to bring her up like her brothers or follow the traditional dictates. Interestingly in an abstract way, the reader is also able to comprehend the protagonist's own confusion from the same excerpt. After her admission of finding more comfort in her brothers' leftover shirts and trousers; one notices a shift in her interest of dresses. Because of the family's financial state, she could not easily access fancy clothes but the passages dedicated to the 'used' pretty frocks and shoes that she got from her rich cousin in itself is an implication of the gradual process of the acquired feminine psychology.

\section{Menstruation and its psychological effects}

The reader notices that while Lieno related the psychological trauma every girl went through during puberty, she remained silent about her own sexuality. She was realistic in her presentation of menstruation as a taboo and its psychological effects. For instance, how her grandmother's reference of menstruation as the "curse" only made it more repugnant and humiliating for her. This disgusting humiliation soon developed into a phobia in her which was evident in her dream, 
At night I dreamed that I was in school, sitting in class when there was a lot of screaming and it was the bigger girls doing the screaming. They were all bleeding and the classroom was filling up with their blood and some of them were drowning in their own blood but they were still screaming. Then all of them began to call me. I woke up with a start but I continued to hear them screaming and calling my name. (p.136)

During puberty both a boy and a girl's body undergo changes. But while the changes are easily embraced by the boy, such as the growth of hair in his body is a matter of pride to be exhibited; the same is a matter of disgust for a girl. And with the monthly period recurring, she feels alienated from her own body and correlates that phenomenon to losing her control over her 'Self'. In addition to that she also knows that this contemptible phenomenon is also known to men, adding to her humiliation. Hence that explains the persistent hesitation of Lieno to buy Comfits from the male shopkeeper in the narrative.

Her narrative on menstruation exhibits her fear and at the same time excitement of now being a 'big girl'. The hours that she spent thinking about this mysterious malady that is the fate of every woman also directs her thoughts towards pregnancy. She discussed about it with such ardour with Vimenuo. This is but only a universal experience of every young girl who enters puberty. However, it is but unnatural to find no expression of Lieno's complex web of adult desires. Early in the novel the narrator gives her impression of the women in the pond and in drinking houses. Here again the opinion that she has is an acquired one. The elders around her reminded her that girls who laugh too much end up being pregnant before marriage and with the family and society discarding them; they find refuge only in drinking houses. Such talks instilled fear in her. But when her grandmother accused her teacher Miss Sobu of corrupting the young minds of her students by getting pregnant before marriage; Lieno questions the allegation as she feels that that's not true. But one thing she learns from that incident is that the society looks down upon such women. In this way even her behavior and thoughts are conditioned. She is promiscuous enough to follow the sexual language of the adults in her locality. Her being able to comprehend what 'Rough customer' (p.122) meant, also hints towards her knowledge of sexual acts though in a vague way. Her discomfort in the presence of the women from the drinking houses is indicative of the social dichotomy of good and bad girls. Therefore, the silence that she maintains in her narrative about her sexuality is an act of repression, which in turn is the outcome of her fear of being 'gazed' by the society. The narrator does not give any details about her opinion regarding her marriage in the epigraph. A proposal came for her and,

"...we were married in about six months after the offer was accepted." (p.314)

Though she refers to her Aunt Benuo's remark that she is not a good wife material; the reader does not find anything unconventional in her. Except for one instance where she speaks up to Vini as to how his aggressive behaviour is breaking up his family; she is, most of the time silent. Almost all her act of questioning the system takes place only in her mind. In fact, she readily takes up the role that was assigned to her as a child and defends her domestic role as a contribution to the family. And this realization gives a fake sense of importance to her and she finally succumbs to the system. 
I felt a new sense of worth. I was not unfortunate to have been born a girl. Mother and Father were grateful for the things I was able to do at home. My brothers would not have been able to do what I did, the cooking and washing and cleaning. Bulie often said, "I'd rather work overtime at the garage than have to cook and scrub as you do, Lieno." (p.276)

\section{Conclusion}

'Gender' as a concept is socially constructed. It is propagated through a mechanism that is imposed by the society to make a woman out of a female. Lieno is, thus, justified in addressing her grandmother " $A$ Terrible Matriarchy" for the legacy that she has left in her granddaughter. It was at her grandmother's house that Dielieno had experienced gendered based discrimination because she was a girl. She was made to feel inferior, unwanted, unloved and uncared for unlike her four brothers. The infliction of Grandmother's treatment upon her young mind was so intense that she had even wished to die rather than staying at her house in her presence. But Dielieno did not succumb to the humiliating treatment of her grandmother, a child of patriarchy, who exerted all her energy in the prospective metamorphosis of her granddaughter into a good woman. Instead, she forgave her for all her suffering. And with the support of her mother and elder brother, she managed to graduate and become a teacher. Her bitterness for her grandmother was transformed into forgiveness after she could comprehend the social dilemma faced by her grandmother's generation in the past when Naga men were deemed to be warriors and protectors of the family.

\section{References}

Alban, Gillian. M.E. (2013). "Medusa as Female Eye or Icon in Atwood, Murdoch, Carter, and Plath" Mosaic: a journal for the interdisciplinary study of literature.46(4). 163-182. Doi: 10.1353/mos.2013.0045

Angami Naga. en.wikipedia.org/wiki/Angami_Naga

Angami Tribe. indianmirror.com/tribes/angamitribe.html

Bamberger, Joan. "The Myth of Matriarchy: Why Men Rule in Primitive Society". 263-280. Retrieved 21 June 2021 from https://radicalanthropologygroup.org/sites/default/files/pdf/class_text_052.pdf

Beauvoir, Simone. (1989). The Second Sex. Vintage Books Edition, New York.

Bowers, Susan R. (1990). "Medusa and the Female Gaze." NWSA Journal, 2(2),217-235. Retrieved 21 $1^{\text {st }}$ June, 2021 from https://www.jstor.org/stable/4316018 .

Burns-Ardolino, Wendy A. (2003). "Reading Woman: Displacing the Foundations of Femininity" Hypatia, 8(3), 42-59, Indiana UP. Retrieved $21^{\text {st }}$ June,2021 from https://muse.jhu.edu/journals/hyp/summary/v018/18.3ardolino.html.

Bussey, Kay \& Albert Bandura. "Social Cognitive Theory of Gender Development and Differentiation",1-63. Retrieved from http://www.google.com/url?sa=t\&source=web\&rct=j\&url=https://www.uky.edu/ eu she2/Bandura/Bandura1999PR.pdf\&ved=2ahUKEwibr_H_-MTxAhVVOSsKHWpBa4QFjABegQIAxAG\&usg=AOvVaw3pIWcj-0s5V6BSTtEVxuxz

Foucault, Michel. (1997). Ethics: Subjectivity and Truth, The New Press, New York. 
9 The Metamorphosis of a Female Subject into a Gendered subject: A Study of Easterine Iralu's A Terrible Matriarchy

Iralu, Easterine. (2007). A Terrible Matriarchy, Zubaan.

Millet, Kate. "Chapter 2 of "Sexual Politics" Theory of Sexual Politics" MIA: Subject: Women and Marxism. Retrieved $20^{\text {th }}$ June, 2021 from https://www.marxists.org/subject/women/authors/millettkate/theory.htm

Millet, Kate. (2003). Sexual Politics, University of Illinois Press.

Rich, Adrienne. (2003). The Kingdom of the Fathers "Feminism: Critical Concepts in Literary and Cultural Studies, Vol.4, Routledge, London and New York.

\section{Authors' Bio-notes:}

Bompi Riba is an Assistant Professor at the Department of English, Rajiv Gandhi University, Arunachal Pradesh. She has been teaching for the last eleven years. She is currently pursuing her Ph.D in Diaspora Studies and her area of interest includes the Politics of Home, Gender Studies and Literature from North East India.

Karngam Nyori is a Research Scholar pursuing her Ph.D at the Department of English, Rajiv Gandhi University, Arunachal Pradesh. Her area of interest includes trauma studies and Literature from North East India. 